\title{
Eraikiriko ondarearen birgaitze energetikoaren onurak eta arriskuak: bost esku-hartze maila
}

\author{
Benefits and risks of energy rehabilitation: \\ 5 intervention degrees in built heritage
}

\author{
Eneko Jokin Uranga*, Lauren Etxepare, Maialen Sagarna, Iñigo Lizundia \\ Arkitektura Saila, Euskal Herriko Unibertsitatea (UPV/EHU) \\ *enekojokin.uranga@ehu.eus
}

DOI: $10.1387 /$ ekaia.16380

Onartua: 2016-07-06

Laburpena: Bi auzik eragingo diote datozen urteotan eraikiriko ondarearen birgaitze energetikoari: aurretiko eraikin eta bizitetxeen gainean energia-eskaera murrizteko helburuz esku hartzeko beharrak, batetik, eta eraikiriko arkitektura-ondarea zaintzeko beharrak, bestetik. Esku-hartze eta birgaitze-estrategiek, baina, energia-eskaeraren murrizketa beste helbururik izan ezean, luze gabe gerta liteke geure parke eraikia itxuraldatua suertatzea, jatorrizko arkitektura-ezaugarriak erabat galduta. Horrez gain, gure herri eta hirietako parke eraikia babesteko arauek eta legeek ezinezkoa eginez gero etxe eta eraikinen birgaitze energetikoa aurrera eramatea, ez da Europar Batasunak ezarritako helburuekin konplitzerik izango. Lan honek mutur bi horien arteko dialektikari erantzun mailakatua ematea du helburu. Alde batetik, bost esku-hartze maila proposatzen ditu. Maila bakoitzak jatorrizko eraikinaren izaerari eta inguruabarrei erantzuten die, eta maila bakoitzari, noski, kontsumo-hobekuntza jakin bat dagokio. Beste aldetik, gure herri eta hirietan ohikoenak diren etxe tipo nagusiak hartzen ditu saiakuntza-bankutzat, esku-hartze maila ezberdinen eragina neurtzeko.

Hitz gakoak: birgaitzea, energia, arkitektura-ondarea, eraikingintza, esku-hartzea.

\begin{abstract}
Two events are going to mark the energy rehabilitation of built heritage over the coming years: on the one hand, the need to carry out energy interventions on existing buildings in order to achieve the objectives established by the European Union, and on the other, the preservation of the built heritage. If the type of intervention imposed is one that is carried out in any way, with no other purpose than achieving purely energy-related objectives, the housing stock of our towns and villages may end up disfigured and stripped of its original architectonic features. If a large part of the building stock is protected meaning that it is impossible to carry out the energy rehabil-
\end{abstract}


itation, achieving the objectives set out will not be possible. The aim of this work is to respond gradually to this dialectic, proposing 5 degrees or levels of intervention, depending on the characteristics and context of the building, and resulting in a certain level of improvement insofar as energy consumption is concerned.Finally, the most common residential types in the basque towns and cities are considered as a test bed, in order to assess the influence of the different degrees of intevention.

Keywords: rehabilitation, energy, architectural heritage, building, intervention.

\section{SARRERA}

Eraikinen energia-eraginkortasunari buruzko 2010/31/EB Zuzentaraua [1] eta energia-eraginkortasun orokorrari buruzko 2012/27/EB Zuzentaraua [2] onartu ostean, asmo handiagoko helburuak ezarri dira, 2020a baino lehen Europar Batasuneko estatu-kide bakoitzaren baitan araudi zorrotzago bat aplikatua izan dadin. Espainiari dagokionez, hauek lirateke helburu nagusiak: eraikinen energia-eraginkortasunari buruzko ziurtapenaren gaineko araudia [3] aldatzea, eta Eraikingintzako Kode Teknikoaren HE Energia aurrezteko oinarrizko dokumentua aldatzearen ondorioz dauden eskakizun berriak betetzea [4]. Onartutako araudi berri horrek dio, lehendik dauden eraikinei buruz, helburu orokorrak bete beharrekoak direla haietan esku hartuz gero.

Hori horrela, baliteke zalantzak sortzea araudia zer kasutan aplikatu behar den. HE Energia aurrezteko oinarrizko dokumentu berriko HE 1 atalean -Energia-eskaria mugatzea - ezarritako aplikazio-eremuari begiratzen badiogu, hau dio: «lehendik dauden eraikinetan esku-hartzetzat jotzen dira handitzeko, eraberritzeko eta erabilera aldatzeko egiten diren lanak». Eta honela deskribatzen ditu eraberritzeak: «lehendik dagoen eraikin batean mantentze-lan esklusibo gisa egiten diren lanez gaindiko beste edozein lan». Horren arabera, beraz, mantentze-lanetatik aparte egiten den beste edozein jardueratan, aplikatu egin behar da birgaitze energetikoa, arauak eskatutako parametroetan. Hori horrela izanik, hurrengo urteetan, eraikin gehienetan egingo dira energia-eskaeraren hobekuntzarekin lotutako esku-hartzeak.

Bestalde, arau horrek berak salbuespen garrantzitsu bat egiten du; izan ere, araua betetzetik kanpo geratzen dira «eraikin historiko babestuak, babes historiko-artistikoari buruz irizpena eman behar duen organo eskudunak hala erabakitzen duenean». Kontuan izanda gaur egun gero eta higiezin gehiagok dituztela, balio historiko-artistikoak ez ezik, kontserbatu eta babestu beharreko beste balio mota batzuk, litekeena da eraikiriko ondarearen babesari buruzko eskumena duten administrazioek energia-araudia aplikatzeko esparrutik kanpo uztea hainbat eraikin.

Eraikinen babesaren eremuan, nolanahi ere, dena ez da zuria ala beltza, edo bestela esanda, guztiz babestekoa ala batere ez babestekoa. Babes- 
Eraikiriko ondarearen birgaitze energetikoaren onurak eta arriskuak:

bost esku-hartze maila

maila ezberdinak ezarri ahal dira, erlazio orekatu bat emango dutenak eraikinaren jatorrizko arkitektura-lengoaiaren zaintzaren eta eraberritu izanak lekarkeen energia-eskaeraren murrizketaren artean. Babes horiek estatu mailakoak izan ahal dira, Euskal Autonomia Erkidego mailakoak, edota tokian tokiko udalek arauturikoak.

Artikuluak bi mutur horien arteko dialektikari erantzun mailakatua ematen ahal zaiola erakustea du helburu. Alde batetik, bost esku-hartze maila proposatzen ditu; maila bakoitzak jatorrizko eraikinaren izaerari eta inguruabarrei erantzuten die. Esku-hartze apalenek apenas emendatzen duten itxitura-elementu ezberdinen isolamendu-gaitasuna; handienen eskutik, berriz, erabateko murrizketa gertatzen da bero-galeretan. Maila bakoitzak, noski, balio-tarte jakin bat emango luke, energia-eskaeraren hobekuntzari dagokionez. Artikuluak, azken atalean, gure herri eta hirietako etxe tipo esanguratsuenak hartzen ditu saiakuntza-bankutzat, esku-hartze maila horien eragina zenbatesteko asmoz: zer babes-maila dagokien, zein duten jatorrizko klase enegetikoa, eta zer neurritan murriztu ahal den euren energia-eskaera.

Lan honek etxeen eraikuntza-elementuen gainean aplikatu ahal diren estrategia pasiboak baino ez ditu aintzat hartzen, elementu horien isolamendu-gaitasuna emendatzera datozenak, alegia. Albo batera uzten ditu energia-sistemen balizko hobekuntzak, azken horien gainekoek ez baitiote eragiten eraikinaren konposizioari, ez eta arkitektura-ondareari ere, ondorioz.

\section{BIRGAITZE ENERGETIKOA ETA ERAIKIRIKO ONDAREA}

Espainiako parke eraikia 9.814.785 eraikinek baino gehiagok osatzen dute, eta horietatik \% 99 baino gehiago bizitetxeak dira (25 milioi etxebizitza) [5]. Bada beste datu esanguratsu bat: higiezin horietatik \% 56 baino gehiago eraikita zeuden inguratzailearen transmitantziari gehienezko balio batzuk ezartzen zizkion lehen araudia indarrean sartu zenerako [6]. Hori dela eta, higiezin horietatik gehienek energia-portaera kaskarra dute. Multzo horretako eraikin gehienak bizitetxeak dira, eta eraikin horietan esku hartu beharko da, hain zuzen ere, energia-eskaerari buruzko helburuak beteko badira.

Azken horretan Espainian indarrean sarturiko zenbait arauk, halanola 8/2013 Legeak (hiri-birgaitze, berroneratze eta eraberritzeari buruzkoak [7]), energia-eskaera murrizteko beharra eta, beraz, parke eraikia birgaitzeko beharra aurreikusten dute. Gainera, azterketa kontrastatu zenbaitek behar hori eraikuntzaren sektorea ekonomikoki suspertzeko aukeratzat jotzen dute [8]. 
Bada, ordea, birgaitze energetikoa geldiaraz dezakeen auzi bat; izan ere, gero eta eraikin gehiago hartzen dira eraikiriko ondaretzat. 2000ko Krakoviako Gutunaz geroztik [9], asko zabaldu da eraikiriko ondarearen adiera eta eremua. Jada ez dira garrantzi historiko-artistiko handia duten higiezinak bakarrik hartzen arkitektura-ondaretzat edo eraikitako ondaretzat; kulturaren, oroimenaren edo, besterik gabe, ingurunearen ikuspegitik interesgarriak izan daitezkeen eraikinak ere elementu baliotsutzat har baitaitezke.

\section{ESKU-HARTZE ENERGETIKOA: BOST MAILA}

Kontuan hartzen badugu zer arazo sor daitekeen bi planteamenduak - esku-hartze energetiko eraginkorra eta ondarearen kontserbazioa - bateratzea lortzen ez bada, litekeena da urte gutxi batzuen buruan energia-helburuak betetzea, baina, energia gutxiago kontsumitzearen ordainean, gure hiriak desitxuratzea. Edo are okerrago, beste muturretik, higiezin historiko gehienak, ondasun higiezinen inbentario berrien onespena dela medio, babestuak suertatzea, eta, ondorioz, ezinezkoa izatea horien gaineko energiaeskaera murrizteko esku-hartzerik egitea [10].

Hona jarraian, sarreran azaldu bezala, eraikiriko arkitektura-ondarearen gaineko esku-hartze mailakatu baten proposamena, hasieratik hartzen duena kontuan higiezinaren izaera eta ingurunea. Izan ere, higiezin sailkatuak babesteko mailak ezarrita dauden modura, esku-hartze energetikorako mailak ezartzean datza artikulu honen funtsa. Proposamenak etxearen barneko atondura eta sareen berrikuntzak alde batera utzi, eta itxituraren eta teilatu-estalkien gaineko esku-hartzeak baino ez ditu aintzat hartzen: zurezko galeria zahar bat aluminiozko elementuekin ordezkatzea, harrizko itxitura historiko bat poliestirenozko xaflekin estaltzea, edota XX. mendeko 60etako etxe baten ageriko adreiluzko itxitura fatxada aireztatu batekin estaltzea; denek egiten diete eraso, neurri batean edo bestean, eraikinaren jatorrizko konposizioari eta nortasunari.

Bost esku-hartze energetiko maila proposatzen dira, 0 maila delarik abiapuntu - higiezina gaur egun zer egoeratan dagoen aztertzea - eta IV. maila muga - esku-hartzerik handiena-. Maila horien artean gelditzen dira energia-eraginkortasunaren hobekuntza neurri batean edo bestean dakarten operazioak, eta baita ondarearen babesaren mailakatze erregresibo bat ere. Hala, zenbat eta esku-hartze maila handiagoa, orduan eta berokuntza- eta hozketa-eskari txikiagoa eta energia-eskaera apalagoa; eta baita alderantziz ere: zenbat eta txikiagoa izan esku-hartzea, orduan eta energia-eraginkortasun apalagoa eta kontserbazio-maila handiagoa. 


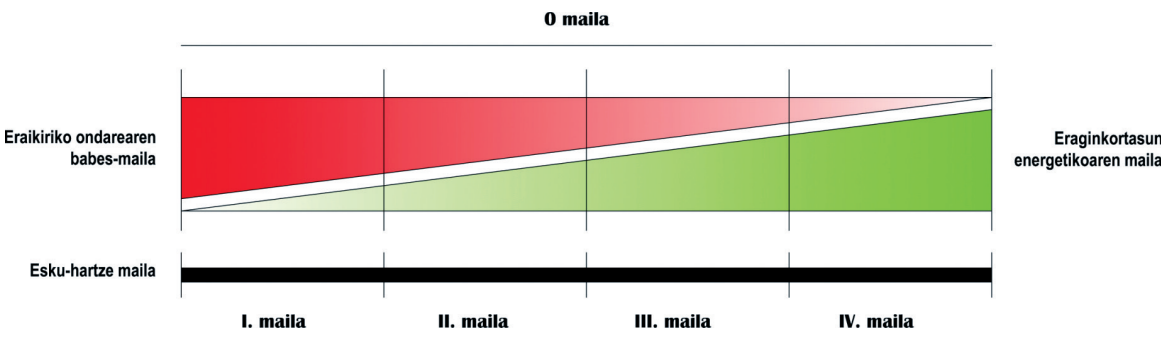

1. irudia. Bost esku-hartze mailak: babesaren eta eraginkortasun energetikoaren arteko erlazioa.

\subsection{MAILA. Jatorrizko egoera}

0 maila edo jatorrizko egoeraren azterketa ez dago berez esku-hartzetzat jotzerik. Izan ere, esku hartuko den higiezinaren unean uneko azterketan datza. Eraikina hiri-ingurune batean dago, forma ematen dioten ezaugarri arkitektoniko jakin batzuk ditu, eta eraikuntza-sistema berezkoak ditu. Edozein esku-hartze mota proposatu aurretik, garrantzitsua da aztertzea zer-nolakoak diren eraikinaren ezaugarriak, eta zer-nola dagoen babestuta. Gainera, energiaren ikuspegitik, aztertu beharreko portaera bat izango du; azken finean, ez badakigu jatorriz zer portaera duen eta zein eskaera-maila dagokion, ez dugu hobekuntzaren neurria zenbatesterik izango.
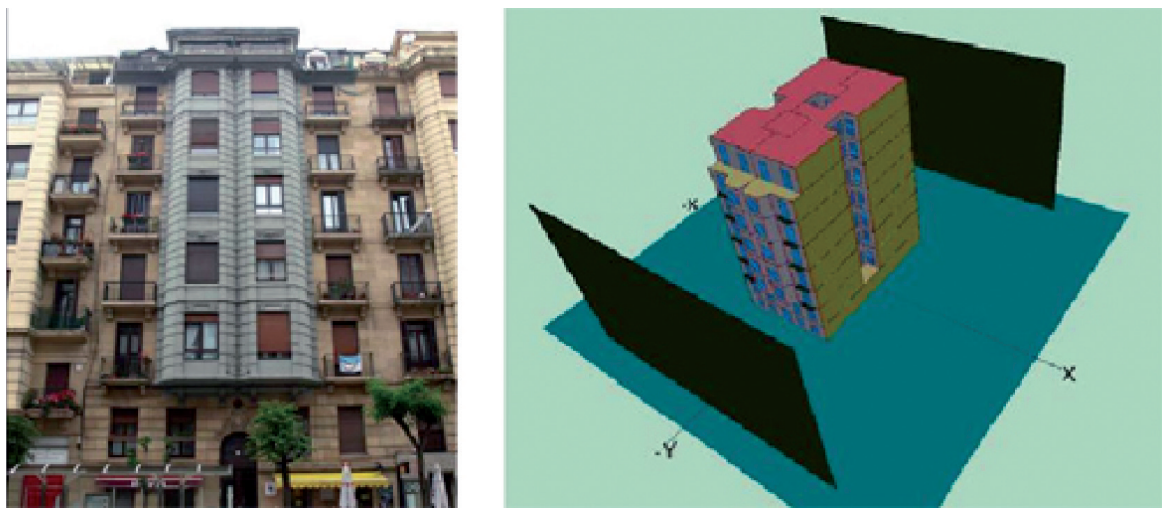

2. irudia. Groseko Colón pasealekuko 15.aren portaera energetikoaren azterketa, 0 esku-hartze mailaren adibide [11]. 


\subsection{MAILA. Kontserbatzea, leheneratzea eta berreraikitzea}

I. mailan, dagoeneko katalogatuta dauden eta, tokiko administrazioaren arabera, ondasun higiezin garrantzitsuenen inbentarioen parte diren eraikinak daude. Etxe baliotsuak inondik ere, arkitekturaren eta artearen ikuspegitik. Esku-hartze energetikoa konplexua izango da, haietan egiten diren lanak kontserbatzeko, leheneratzeko edo berreraikitzeko izango baitira batez ere.
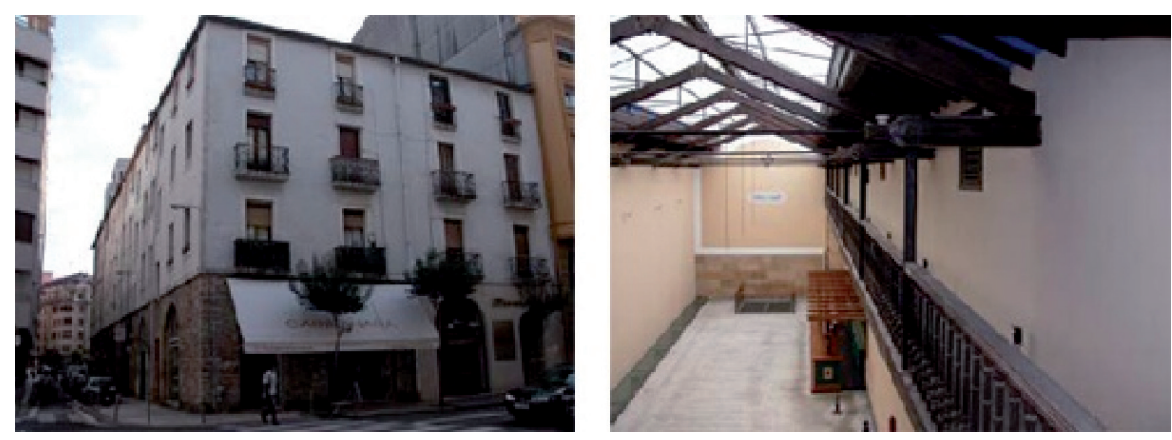

3. irudia. Kale berriko Trinketea, Grosen. Donostiako Eraikitako Hiri Ondarearen Plan Bereziak (EHOPB) Erregimen Orokorreko A mailarekin katalogatua [12], I. mailako esku-hartzea onar lezakeena.

Inbentarioetan baimentzen den esku-hartzea besterik ez da egiterik izango, eta, gehienetan, energia-eraginkortasuna betetzetik salbu geratuko da eraikina, HE Oinarrizko Dokumentuaren HE1 atalean jasotzen den modura. Beraz, eraikinaren ondare-izaerari eustearen ordainean, hobekuntza energetikoa txikia izango da, edota hutsaren hurrengoa. Nolanahi ere, beti izango da interesgarria ikertzea aukerarik ba ote dagoen - txikia balitz ere - energia-hobekuntzaren bat egiteko etxearen fatxadako elementu babestuei kalterik egin gabe.

\subsection{MAILA. Esku-hartze selektiboa}

II. mailan, babes-maila txikiagoa duten higiezinak daude, edo, babestuta egon gabe ere, kontserbatzeko interesgarri diren elementuak dituzten eraikinak. Eraikuntza-elementu isolatuak izan daitezke, balio artistiko edo kultural handirik izan ez arren bereziak direnak. Eraikin-multzoak ere izan daitezke, eta, hain justu, multzoa bera izatea kontserbatzea merezi duena.

Maila hau, batez ere, gure hirietan dauden eraikinei dagokie, eta, ezaugarri berezirik izan gabe ere, hiriaren bereizgarri diren etxeei. Higiezin ugari direnez gero, ez dago haien gaineko esku-hartze energetikoari uko 
egiterik. Esku-hartzeak, ordea, zenbait balio errespetatu behar ditu; horren ondorioz, esku-hartze energetikoak selektiboa izan behar du, elementu jakin batzuen gainekoa, jatorrizko balio arkitektonikoak desitxuratu gabe. Eraikinaren nortasunari eutsita beti ere, elementu batzuk konpondu, ordeztu eta baita aldatu ere egin ahalko dira, hala nola leihoak eta teilatuak, baina soilik kontserbazio-baliorik ez dutenak. Soluzio misto bat da, non balio positiboak eskuratzen ahal diren energia-eskaeraren hobekuntzari dagokionez, betiere ondare-izaera ematen dioten elementu eta ezaugarriei eutsita.
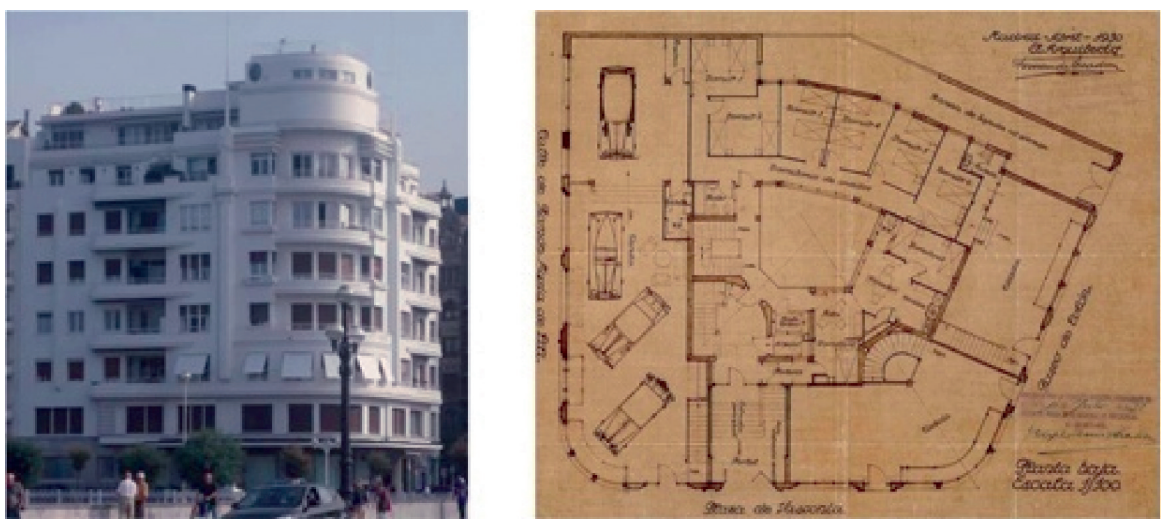

4. irudia. Donostiako Equitativa eraikina (1930). Arkitektoa: F. Arzadun. EHOPBk Erregimen Orokorreko C mailarekin katalogatua. II. esku-hartze maila aplika lekioke.

Lortuko diren energia-emaitzak ez dira indarrean dagoen araudiak eskatutakoetara iritsiko. Eskatutako gutxieneko energia-eraginkortasunaren erdibidean geratuko dira, \% 30etik \% 80ra bitartean. Gure hirietako zentro historikoak gaur egun ezagutzen ditugun bezala uzteak konpentsatuko luke huts hori.

\subsection{MAILA. Esku-hartze masiboa}

Aurrekoa bezalako soluzio mistoa izanagatik, ezarritako energia-helburuak lortu ahalko lirateke esku-hartze masiboa tarteko. Kasu honetan, II. mailan ez bezala, interbentzioak eraikinaren irudia eta forma partzialki aldaraz ditzake. Hala, esku-hartze sakonago baten ondorioz, energia-hobekuntza maila hobeak lortu ahal dira, indarrean dagoen araudia beteta. Eraikinaren inguratzailea osatzen duten elementu askoren gainean aplikatzen dira hobekuntzak; hori dela eta esaten ahal zaio esku-hartze masiboa. 

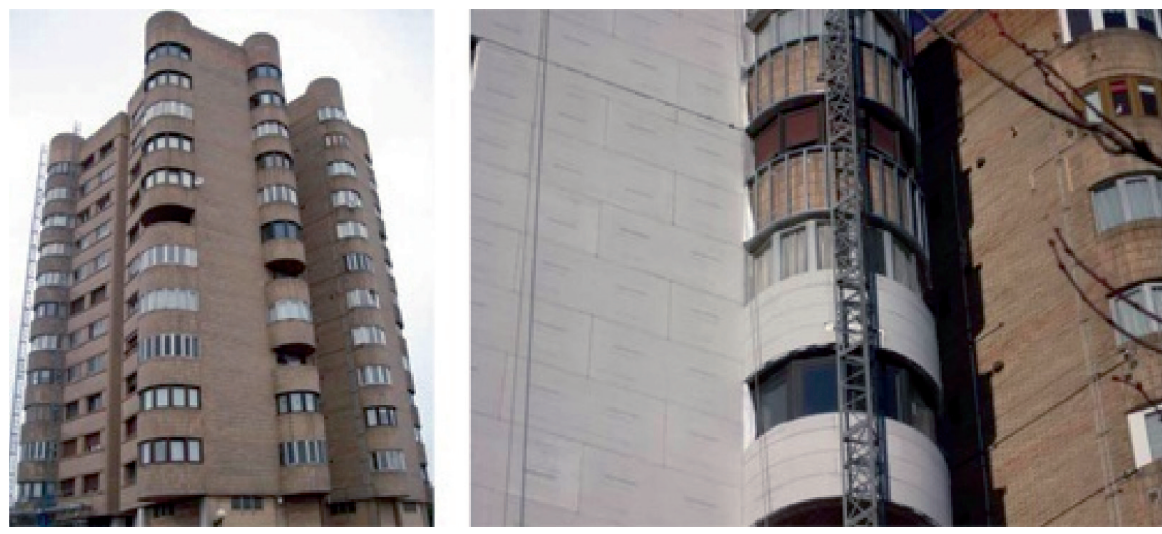

5. irudia. III. esku-hartze mailaren adibidea: Errenteriako Sorgintzuloko dorrean egindako zaharberrikuntza.

Ez da aplikagarria, noski, elementu babestuak dituzten eraikinetan. Eraikinaren bolumena eta profila mantendu egiten dira, baina beste irudi bat ematen zaio material, sistema eta eraikuntza-ebazpide berriak aplikatuta.

\subsection{MAILA. Esku-hartze inbaditzailea}

Azken maila honetan, modu inbaditzailean jarduten da; hau da, jatorrizko higiezina euskarri gisa erabiltzen da soluzio eta sistema berriak ezartzeko edo eraikina handitzeko, eta energia-eraginkortasuna da proposatzen den esku-hartze berriaren ondorio eta argudio nagusia. Horren ondorioz, atal eta espazio berriak sortuko dira, bai eta bolumenaren eta eraikuntzaezaugarrien antolaera berria ere. Arkitektura berria sortuko da, azken batean, esku-hartze energetikoaren ondorioz.
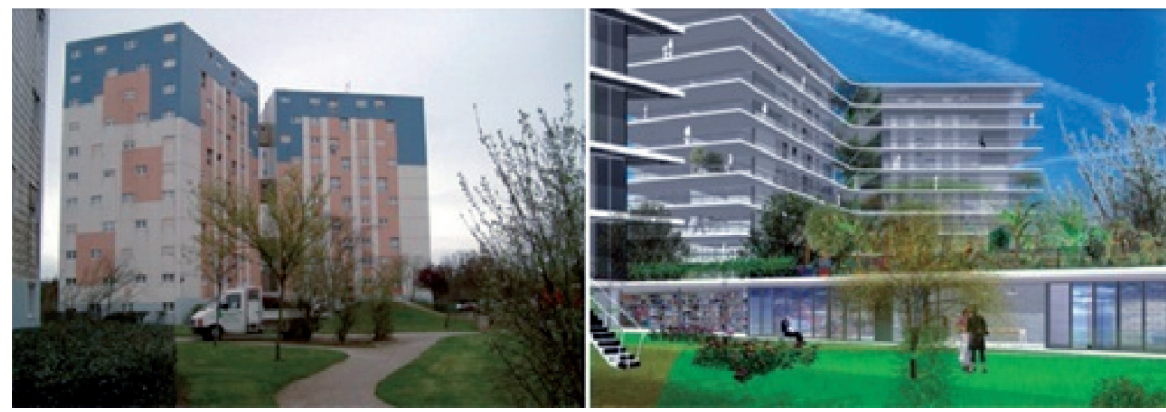

6. irudia. IV. esku-hartzean oinarrituriko proposamen inbaditzailea, Frantziako Trignac hiriko Certé auzoan, F. Druot, A. Lacaton eta J.P. Vassal arkitektoek egindakoa [13]. 
Horrelako esku-hartzeetan, maximoak izango dira kontsumo-mailaren hobekuntzaren gaineko eskakizunak, eta, are, litekeena da eraikinak NZEB (Nearly zero-energy building) estandarra bereganatzea [14] edota, areago, Passive House estandarra eskuratzea ere [15], operazioaren ondorioz eraikin berria bilakatuko balitz bezala. Jatorrizko higiezinaren kontserbazioa alde batera geratzen da guztiz, eta esku-hartzearen ondoriozko eraikinean ikusiko da jatorriko arkitekturatik zerbait gordetzen den ala ez.

\section{BABESAREN ETA ESKU-HARTZEAREN ARTEKO OREKA}

Azalduriko esku-hartze mailek zein neurritako hobekuntza dakarten argitu artean, baina, ez dago euren gaineko gogoetaren baliagarritasuna epaitzerik; hala nola ondare arkitektonikoa zaindu izana irizpide estetiko eta historikoak tarteko ebaluatzen den, esku-hartze bakoitzaren ondoriozko hobekuntza, energia-eskaeraren murrizketaren ikuspegitik, kuantitatiboki neurtu behar da. Hobekuntzaren neurria, ordea, eraikinari ezarritako babesaren araberakoa ez ezik, etxearen eraikuntza-ezaugarrien eta, halaber, forma-ezaugarrien araberakoa izango da: eraikinaren bolumenaren eta konpazitatearen araberakoa.

Har ditzagun saiakuntza-bankutzat, Euskadiko etxebizitza-parkea neurri handian ordezkatzen baitute, 1900 eta 1980 urteen artean Gipuzkoan eraikiriko bost etxe mota sarrienak [16]. Laurogei urteko epealdia hormigoi armatua gurean aurrenekoz erabili izan zen garaiak zabaltzen du, eta gutxieneko isolamendu termikoa ezarriko zuen lehen lege espainiarra indarrean jarritako urteak ixten [6]. Egia bada ere multzo honek, eraikin kopuruari dagokionez, etxeen erdia baino ez duela hartzen, bere adierazgarritasuna, ordezkatzen duen etxebizitza kopuruaren ikuspegitik, esanguratsua da oso; izan ere, egungo etxebizitzen \% 701900 eta 1980 urteen artean izan zen eraikia [17]. Azter dezagun zein den euren gaur egungo energia-eskaera, eta, ondoren, adieraz dezagun zein neurritan murriztu ahal den kontsumo hori, esku-hartze bat edo bestea aplikatuz, etxe mota bakoitzari dagokion babesmaila aintzat harturik betiere. Azterturiko etxe tipoak aurkeztuko ditugu.

\subsection{A tipoa (1900-1920). Zabalguneen eraikuntzaren amaiera}

Xx. mendeko hastapen-urteetan eman zitzaion amaiera Donostiako Cortazar zabalgunearen eraikuntzari, eta baita hasiera eman ere Groseko zabalgunearen eraikuntzari. Etxe ugarik osatuak dira biak ala biak. Groseko Colón pasealekuko 15.a hartuko dugu adibidetzat: Mehelinen artean kokatua, $22 \mathrm{~m}$ sakon eta $12 \mathrm{~m}$ zabal oinean, eta7 solairu garai; $2.088 \mathrm{~m}^{2}$-ko itxitura eta $6.048 \mathrm{~m}^{3}$-ko bolumena. Eraikin konpaktua da $(2,90)$. Itxiturak harrizko hormez eginikoak dira $\left(1,91 \mathrm{~W} / \mathrm{m}^{2} \mathrm{~K}\right.$-eko transmitantzia), eta aurrealdean hormigoizko begiratoki zabal bat dauka $\left(2,5 \mathrm{~W} / \mathrm{m}^{2} \mathrm{~K}\right.$-ekoa). Tei- 
latu lau batek estaltzen du. Leihoak, jatorriz, zurezko arotzeriekin eta xafla bakarreko beirarekin eginak dira $\left(2,4 \mathrm{~W} / \mathrm{m}^{2} \mathrm{~K}\right.$-ekoak). Ez du inon baliatzen isolamendurik.
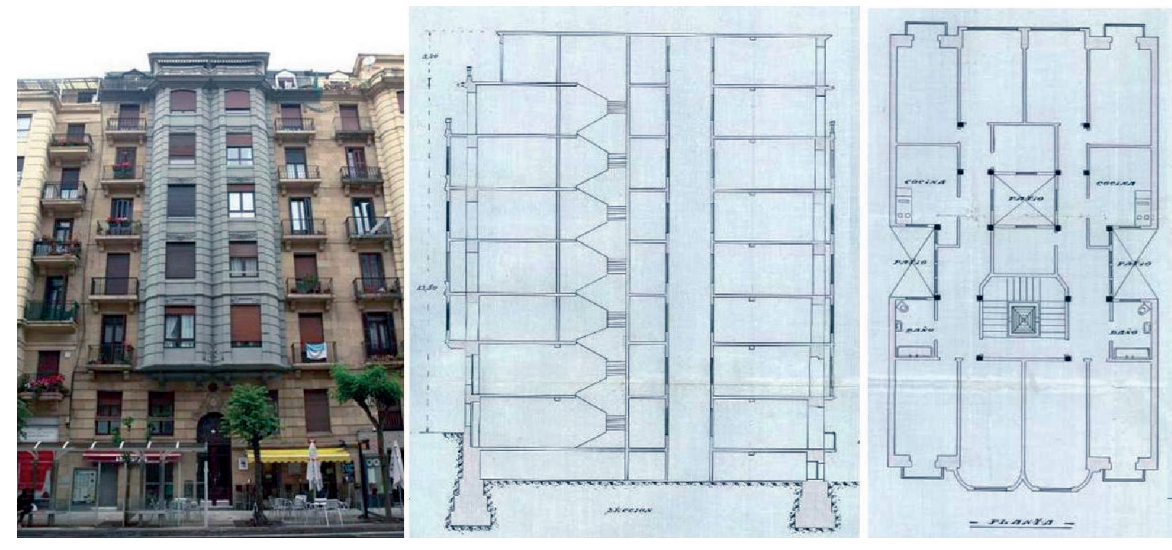

7. irudia. Groseko Colón pasealekuko 15.aren altxaera, ebakidura eta oina (1920).

\subsection{B tipoa (1911-1939). Etxe merkeak}

1921eko Etxe Merkeen Legeak eta 1925eko Etxe Ekonomikoen Errege Dekretuak mugarri suertatu ziren etxebizitza sozialari dagokionez, eta indarrean jarraitu zuten are Bigarren Errepublikan ere. Klase ertaineko sendi bakarrentzako etxeak izan ohi ziren, bi solairukoak [18]. Har ditzagun adibidetzat Anakako etxe merkeak, Irunen, 1926an Teodoro Anasagasti arkitektoaren proiektuaren arabera eraikitakoak. $326 \mathrm{~m}^{2}$-ko itxitura dute, $384 \mathrm{~m}^{3}$-ko bolumena eta konpazitate txikikoak $(1,18)$ dira. Itxiturak eskuharrizko karga-hormekin eraikiak dira $\left(2,18 \mathrm{~W} / \mathrm{m}^{2} \mathrm{~K}\right.$-ekoak), zoruan zuzenean bermaturiko zolarri baten gainean, eta zuraje baten gaineko teilatu batekin estaliak $\left(3,20 \mathrm{~W} / \mathrm{m}^{2} \mathrm{~K}\right.$-ekoa). Ez dute batere isolamendurik. Leihoak aurreko kasuan bezalakoak dira.
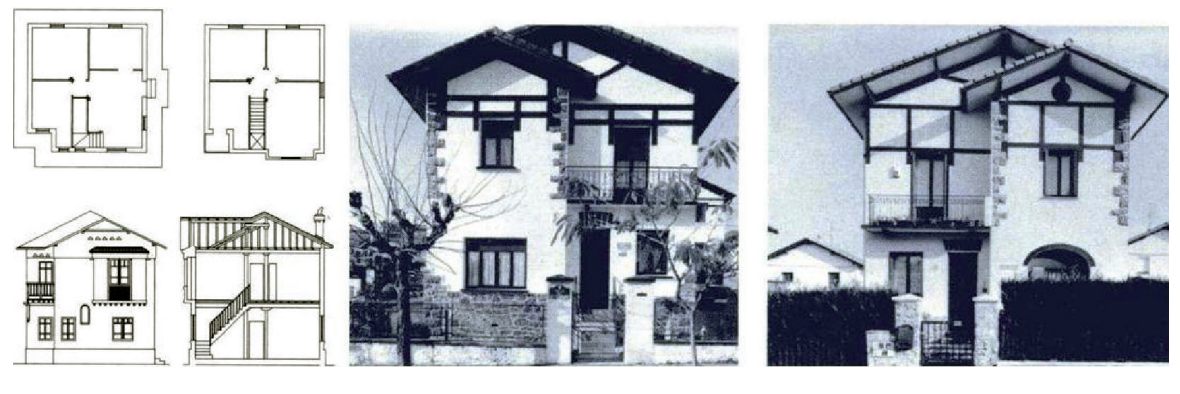

8. irudia. Anakako etxe merkeak, Irunen (1926). 


\subsection{C tipoa (1940-1950). Gerraosteko etxebizitza soziala}

Instituto Nacional de la Vivienda gerraosteko erakunde berriaren eskutik ailegatu zen Lehen Etxebizitza Plan Nazionala (1944-54). Garai hartako eraikin tipo nagusiak luzerako blokea zuen oinarri [19]. Hiru edo lau solairukoak izan ohi ziren, eta bizitzek alderik alde hartzen zuten eraikina. Har dezagun eredutzat 1943an Arrasaten eraikiriko Grupo General Mola multzoa, Ramón Martiarenaren proiektuaren emaitza baitira. Luzetarako blokea da, eskailera erdian duena, eta bi bizitza ditu solairuko. $832 \mathrm{~m}^{2}$-ko itxitura $\left(1,71 \mathrm{~W} / \mathrm{m}^{2} \mathrm{~K}\right.$-ekoa) du, $1.536 \mathrm{~m}^{3}$-ko bolumena eta tarteko konpazitatea $(1,85)$. Leihoak zurezkoak eta xafla bakarrekoak $\left(2,4 \mathrm{~W} / \mathrm{m}^{2} \mathrm{~K}\right.$-ekoak) dira. Adreilu trinkozko hormekin altxatutakoa da, isolamendurik gabe. Solairuak hormigoizkoak ditu, eta teilatua hormigoizko lauzaren gainean $\left(1,59 \mathrm{~W} / \mathrm{m}^{2} \mathrm{~K}\right.$-ekoa) eraikia da.
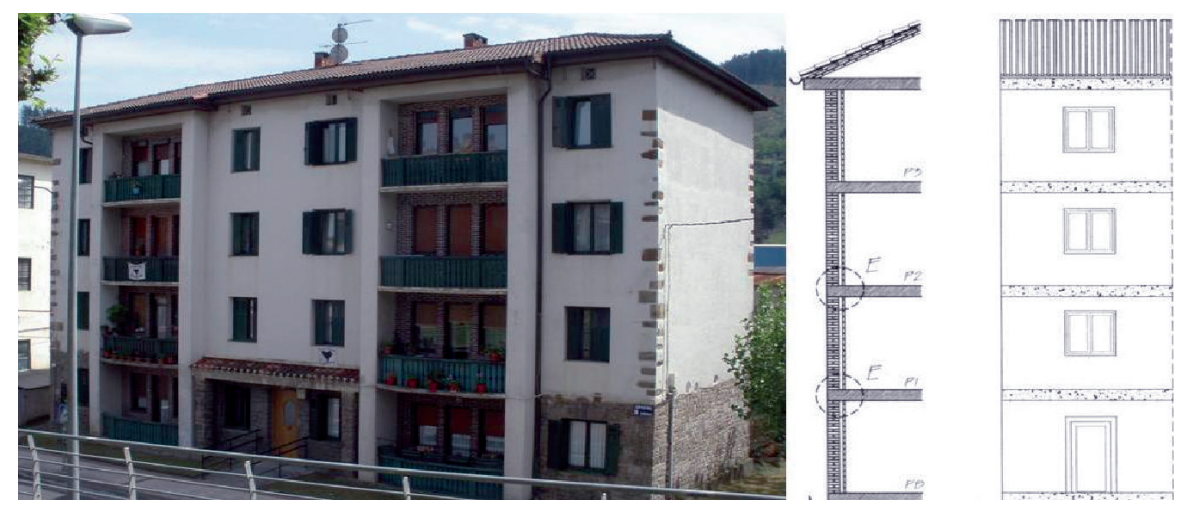

9. irudia. «Grupo General Mola»-ko etxeak, Arrasaten (1943).

\subsection{D tipoa. Hazkundearen garaiaren lehen urteak (1960-1970)}

1956ko Zoruaren Legea indarrean sartu ostean hasi zen garapena eta hazkunde neurrigabea. Lehen urteetan, bloke askeak izan ziren ohikoenak, hiru eta sei solairu bitartekoak, adreiluzko itxitura isolatu gabeekin. 60ko hamarkadak aurrera egin ahala, morteroz zarpiaturiko itxituren ordez, ageriko adreiluzkoak hasi ziren nagusitzen. Har dezagun eredutzat 1961 urtean Zarautzeko Mendilauta kaleko 24.ean eraikiriko sei etxebizitzako blokea. $882 \mathrm{~m}^{2}$ itxitura dauzka, $1.620 \mathrm{~m}^{3}$-ko bolumena, eta tarteko konpazitatea $(1,84)$. Hormigoizko egitura dauka, eta itxiturak adreiluzko orri bikoitzez daude eginak: kanpokoa, zarpiozko akabera daukana, adreilu barnehuts bikoitzeko azta erdikoa da, eta barnekoa, berriz, trenkada arrunta, igeltsuz luzitua $\left(1,72 \mathrm{~W} / \mathrm{m}^{2} \mathrm{~K}\right.$-ekoa). Leiho-arotzeriak zurezkoak dira, eta xafla bakarreko beira dute $\left(2,4 \mathrm{~W} / \mathrm{m}^{2} \mathrm{~K}\right.$-ekoa). Teilatua, isolatu gabea, hormigoizko lauza baten gainean ezartzen da [20]. 


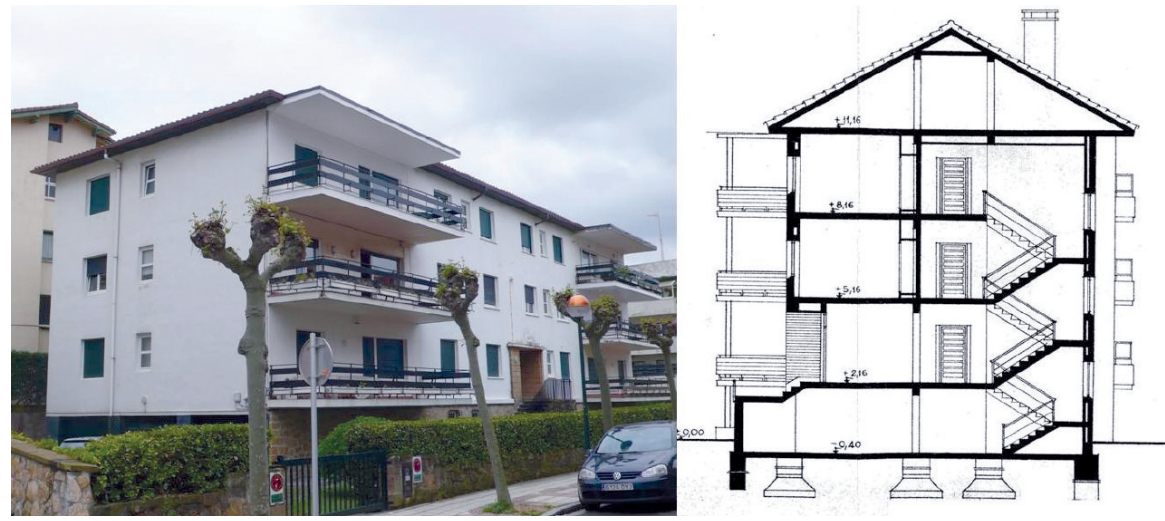

10. irudia. Mendilauta kaleko 24.eko etxebizitzak, Zarautzen (1961).

\subsection{E tipoa. Hazkundearen garaiaren azken urteak (1970-1978)}

Garapenaren eta hazkunde-garaiaren azken urteetan eraikiriko etxeak dira. Aurreko tipoarekiko aldea ez datza eraikuntza-ezaugarrietan; aitzitik, berdintsu daude eraikiak. Aldea, gehienbat, forma eta tamainan dago. Dorreak ziren nagusi. Har dezagun eredutzat 1970ean Errenteriako Capuchinos-eko gainean Félix Llanos arkitektoaren proiektuaren arabera eraikiriko dorre saila. 15 solairuko eraikin lerdenak dira, 16,5 metroko aldeko oin karratukoak eta 44 metro garai direnak. $11.520 \mathrm{~m}^{3}$-ko bolumena dute, eta oso konpaktuak dira $(3,40)$. Egitura hormigoi armatuzkoa dute, eta itxiturak, isolamendurik gabeak, adreiluzko orri bik osatuak dira $\left(1,76 \mathrm{~W} / \mathrm{m}^{2} \mathrm{~K}\right.$ ekoak). Jatorrizko leihoak zurezkoak ziren, eta beirak, xafla bakarrekoak $\left(2,4 \mathrm{~W} / \mathrm{m}^{2} \mathrm{~K}\right.$-ekoak). Solairu-ertz guztiak agerian daude fatxadan, eta baita perimetroko zutabeak ere. Itxitura behin eta berriz zulatzen du barne-egiturak, eta zubi termikoak, beraz, han eta hemen izaten dira [21].
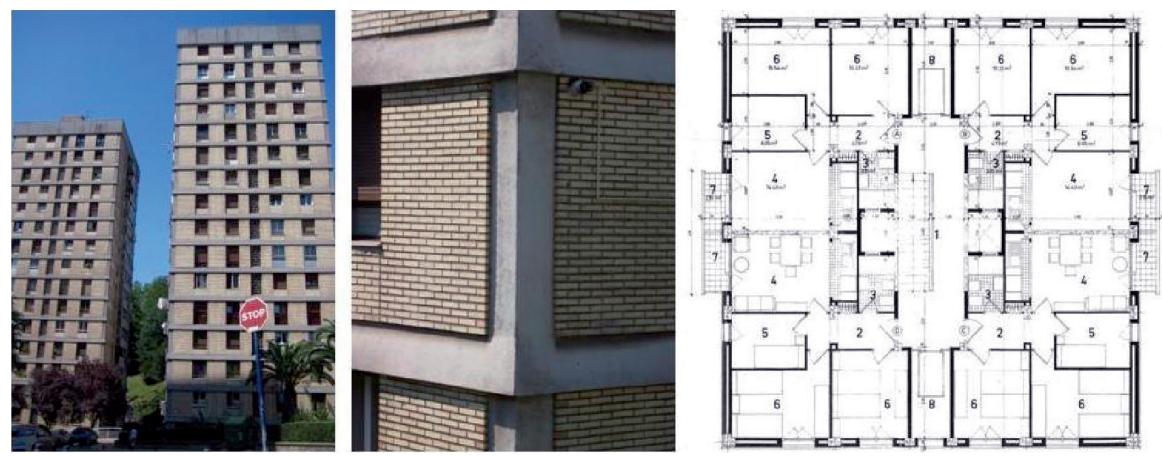

11. irudia. Capuchinos-eko gaineko dorreak (1970). 


\subsection{Erabilitako aplikazioak eta alderaketa-baldintzak}

Honako hauek izan dira hautaturiko etxe-laginaren portaera energetikoa eskuratzeko baliaturiko aplikazio informatikoak, IDAE Energia Dibertsifikatu eta Aurrezteko Institutuak emandakoak:

- LIDER-CALENER (HULC). Eraikingintzaren Kode Teknikoak bere HE1 atalean -Energia-eskaria mugatzea - ezarritakoa egiaztatzeko aplikazioa [22].

- CE3/CE3X. IDAE erakundeak eskainiriko aplikazioa, lehendikako eraikinen egiaztatze energetikoa eskuratzeko [23].

\subsection{Abiapuntuak eta esku-hartze mailen araberako balizko hobekuntza}

Etxetipo jakin bati babes ezberdinak egokitu ahal zaizkio, izan estatu mailako babesa, Euskal Autonomia Erkidego mailakoa, nola udal mailakoa. Erakunde gorenetatik etorritako legeek, orohar, babes-maila handia ezartzen dute, eta, aldiz, Donostiako Eraikitako Hiri Ondarearen Plan Berezia [15] gisako tokiko arauek, malgutasun eta ñabardura-gaitasun handiagoa ageri dute, eraikinak neurri batean ala bestean babesteko. Hona jarraian lege eta araudi esanguratsu zenbait, ezartzen duten babes-mailaren arabera sailkatuak.

1.taula. Babes-mailak, lege eta araudien araberakoak

\begin{tabular}{|c|c|c|c|c|}
\hline & \multicolumn{4}{|c|}{ Babes-mailak } \\
\hline & $\begin{array}{c}1 \\
\text { (handia) }\end{array}$ & $\begin{array}{c}2 \\
\text { (tartekoa) }\end{array}$ & $\begin{array}{c}3 \\
\text { (txikia) }\end{array}$ & $\begin{array}{c}4 \\
\text { (batere ez) }\end{array}$ \\
\hline \multirow[t]{2}{*}{ Orokorra } & $\begin{array}{l}\text { 16/1985 Legeak, } \\
\text { Espainiako His- } \\
\text { toria-Ondareare- } \\
\text { nak, Kultura In- } \\
\text { tereseko Ondasun } \\
\text { izendatuta }\end{array}$ & \multirow[t]{2}{*}{ - } & \multirow[t]{2}{*}{ - } & \multirow{3}{*}{-} \\
\hline & $\begin{array}{l}\text { 7/1990 Legeak, } \\
\text { Euskal Kultur On- } \\
\text { dareari buruzkoak, } \\
\text { Kultur Ondasun } \\
\text { izendatuta }\end{array}$ & & & \\
\hline Tokikoa & $\begin{array}{l}\text { EHOPBk Erregi- } \\
\text { men Orokorreko } \\
\text { A mailarekin kata- } \\
\text { logatua }\end{array}$ & $\begin{array}{l}\text { EHOPBk Erregi- } \\
\text { men Orokorreko } \\
\mathrm{B}, \mathrm{C} \text { edo D maila- } \\
\text { rekin katalogatua }\end{array}$ & $\begin{array}{l}\text { EHOPBk Erregi- } \\
\text { men Orokorreko } \\
\text { D mailarekin ka- } \\
\text { talogatua }\end{array}$ & \\
\hline
\end{tabular}


Etxetipoak ezarririk, euren eraikuntza-ezaugarriak eta ezaugarri formalak aplikazioetan sarturik, testuinguruari eta klimari buruzkoak aintzat harturik (D1 zonalde klimatikoan daude denak), azal dezagun, lehenik, zein klase energetiko dagokion etxe mota bakoitzari hasiera batean, eta zein klase enegetiko erdietsi beharko lukeen gehienez.

Etxe tipo bakoitzari dagokion babes maila ezarrita, hauek lirateke tipo bakoitzak onartu ahalko lituzkeen esku-hartzeak: A etxe tipoak esku-hartze selektiboa onartuko luke gehienez ere, teilatuaren isolamendu-gaitasuna hobetuta edota leiho-arotziak aldatuta; B eta C etxe tipoek esku-hartze masiboa onartu ahal lukete, bere itxiturak ETICS sistemaz estalita [24], adibidez; eta, azkenik, D eta E tipoek, ez baitaude ia inolako babespetan, eskuhartze inbaditzailea onartu ahalko lukete, era guztietako sistemak tarteko: fatxada aireztatuak, beirazko galeriak erantsita eta beste.

Hona jarraian etxe tipo bakoitzean, esku-hartze maila bat edo bestea aplikatuta, eskuratu ahal zitekeen hobekuntzaren kalkulua, LIDER-CALENER eta CE3/CE3X aplikazioen bidez eskuraturikoa.

2. taula. Hobekuntza energetikoa, esku-hartze mailaren eta babes-mailaren araberakoa.

\begin{tabular}{|c|c|c|c|c|c|c|c|c|}
\hline \multirow{2}{*}{ Etxetipoa } & \multirow{2}{*}{$\begin{array}{l}\text { Babes- } \\
\text { maila }\end{array}$} & $\begin{array}{c}\text { Jatorrizko } \\
\text { klase energetikoa }\end{array}$ & \multirow{2}{*}{$\begin{array}{l}0 . \\
\text { maila }\end{array}$} & \multirow{2}{*}{$\begin{array}{l}\text { I. } \\
\text { maila }\end{array}$} & \multirow{2}{*}{$\begin{array}{l}\text { II. } \\
\text { maila }\end{array}$} & \multirow{2}{*}{$\begin{array}{l}\text { III. } \\
\text { maila }\end{array}$} & \multirow{2}{*}{$\begin{array}{l}\text { IV. } \\
\text { maila }\end{array}$} & $\begin{array}{l}\text { Erdietsi beharreko } \\
\text { klase energetiko } \\
\text { gehienezkoa }\end{array}$ \\
\hline & & $\begin{array}{l}\text { Energia-eskaera } \\
\left(\mathrm{kWh} / \mathrm{m}^{2} \text { urteko) }\right.\end{array}$ & & & & & & $\begin{array}{l}\text { Energia-eskaera } \\
\left(\mathrm{kWh} / \mathrm{m}^{2} \text { urteko) }\right.\end{array}$ \\
\hline A & $1-2$ & C/D (60-140) & $\% 0$ & $\% 10$ & $\% 30$ & (1) & (1) & C (60-95) \\
\hline B & $2-3$ & $\mathrm{~F} / \mathrm{G}(335->340)$ & (2) & (2) & $\% 30$ & $\% 50$ & (1) & D/E (95-295) \\
\hline $\mathrm{C}$ & $2-3$ & E/F (145-335) & (2) & (2) & $\% 35$ & $\% 55$ & (1) & $\mathrm{B} / \mathrm{C} / \mathrm{D}(40-140)$ \\
\hline $\mathrm{D}$ & $3-4$ & E/F (145-335) & (2) & (2) & (2) & $\% 60$ & $\% 90$ & A/B (40-60) \\
\hline E & $3-4$ & E (145-295) & (2) & (2) & (2) & $\% 70$ & $\% 100$ & $\mathrm{~A}(<40)$ \\
\hline
\end{tabular}

(1) Ez dago esku-hartze maila hori aplikatzerik, etxearen babes-maila urratuko bailuke.

(2) Ez du zentzurik esku-hartze maila hori aplikatzeak; alde batetik, etxea ez dago hain babestua, eta, bestetik, eskuratuko litzatekeen hobekuntza urruti legoke erdietsi beharreko klase energetikoa ematetik.

\section{ONDORIOAK}

Pendulu-dinamika baten muturretako batean aurkitzen gara gaur egun. Izan ere, gure parke eraikia gaitzetsita dago, energia-portaeraren ikuspegitik. Oso energia-eskaera handikoak dira gure etxeak, eta lehenbailehen jarri behar ditugu abian horien energia-eskaera murrizteko bideak eta estrategiak. Aitzitik, erne ibili beharko genuke, penduluaren beste muturrera ez lerra- 
tzeko, zeren eta, estrategia eta esku-hartzeko bide horien aplikazioaren ondorioz, litekeena da, luze gabe, eskaera-mailak murriztea ez ezik, gure hiri eta auzuneak osatzen dituzten eraikinen izaera desitxuratzea. Guztiz beharrezkoa da, gaur egun eskura dauzkagun esku-hartze sistema integral horiek aplikatu aurretik, hausnartzea zer helburu lortu behar ditugun, eta ez ote den egokiagoa izango esku-hartzea tokian tokikoa izatea, eraikinaren atal edo elementu zenbaiten gainekoa. Izan ere, arkitektura-ondareari buruz ari garelarik, helburuak ez dira soilik energia-eskaeraren araberakoak izan behar.

Energia-hobekuntzaren emaitzari besterik begiratu ezean, arkitektura-ondarea hipotekatzen ariko gara; eta, alderantziz, arkitektura-ondarea gehiegi babesten badugu, gure eraikinak elementu energetikoki eraginkor bilakatzeko aukera galtzen ariko gara. Esku-hartze horiek orekatzeko, interesgarria litzateke, bai eraikinak babesteko ahalmena duten administrazioak bai birgaitze energetikoan parte hartzen duten gainerako eragileak ere, auziari eragiten dioten bi faktoreen jakitun izatea, eta ikuspegi transbertsal batetik erreparatzea gaiari, helburu biak bateratuta.

Ez genuke eragozpenik izan behar baldin eta ikuspegi transbertsal horren ordaina gure etxeen energia-eraginkortasunaren hobekuntzaren parte bati uko egitea balitz, edo bestela esanda, energiaren ikuspegi hutsetik erreparatuta lortuko litzatekeenaren zati bat galduko bagenu bidean.

2. taulari erreparatuz gero, bistan da zein erlazio dagoen etxeen gaineko babes-mailaren eta balizko hobekuntza energetikoaren artean; alegia, eskuhartze mailaren eta hobekuntza energetikoaren artean. Babes handi baten pean dauden etxeetan handia litzateke ordaina; tarteko babespekoetan hobekuntza energetikoa aintzat hartzeko modukoa litzateke, eta babesik gabekoetan, aldiz, eskuraturiko emaitzak, eskaeraren murrizketari dagokionez, handiak lirateke.

\section{BIBLIOGRAFIA}

[1] Europako Parlamentuaren eta Kontseiluaren 2010eko maiatzaren 19ko 2010/31/EE Zuzentaraua, eraikinen energia-eraginkortasunari buruzkoa (moldatua). 2010/06/18ko L153/13 EBAO. https://www.boe.es/ doue/2010/153/L00013-00035.pdf

[2] Europar Parlamentuaren eta Kontseiluaren 2012ko urriaren 25eko 2012/27/ EB Zuzentaraua, energia-eraginkortasunari buruzkoa, eta 2009/125/EE eta 2010/30/EB Zuzentarauak aldatzen dituena, eta 2004/8/EE eta 2006/32/EE Zuzentarauak indargabetzen dituena. 2012/11/14ko L315/1 EBAO. http:// www.boe.es/doue/2012/315/L00001-00056.pdf

[3] 2013ko apirilaren 5eko 235/2013 Errege Dekretua, eraikinen energia-eraginkortasunaren ziurtagiria emateko oinarrizko prozedura onartzen duena. BOE 
89. zk., 2013ko apirilaren 13koa, I. atala, 27.548. or. http://www.boe.es/boe/ dias/2013/04/13/pdfs/BOE-A-2013-3904.pdf

[4] 2013ko irailaren 10eko FOM/1635/2013 Agindua, Eraikingintzaren Kode Teknikoaren «Energia-aurrezkia» HE Oinarrizko Dokumentua - 2006ko martxoaren 17ko 314/2006 Errege Dekretuz onartua- eguneratzen duena. BOE, 219. zk., 67.137. orritik 67.209.era (73 orri), 2013ko irailaren 12koa. http://www.codigotecnico.org/web/recursos/documentos/

[5] Estatistika Institutu Nazionala - INE. 2011ko biztanleriaren eta etxebizitzen zentsua. http://www.ine.es/

[6] REAL DECRETO 2429/79, de 6 de julio, por el que se aprueba la Norma Básica de la Edificación, NBE-CT-79, sobre Condiciones Térmicas en los edificios, BOEn argitaratua, 252, 1979ko urriaren 22an. Eskuragarri: https:// www.boe.es/buscar/doc.php?id=BOE-A-1979-24866

[7] 2013ko ekainaren 26ko 8/2013 Legea, hiri-birgaitze, berroneratze eta eraberritzeari buruzkoa. BOE 153. zk. 2013ko ekainaren 27koa, I. atala, 47.964. orria. http://www.boe.es/diario_boe/txt.php?id=BOE-A-2013-6938

[8] CUCHÍ, A. eta SWEATMAN, P. 2013. Informe GTR 2014. Estrategia para la rehabilitación. Claves para transformar el sector de la edificación en España. Grupo de Trabajo sobre Rehabilitación, Bartzelona.

[9] RIVERA, J. eta PÉREZ, S. 2000. Carta de Cracovia 2000. Principios para la Conservación y Restauración del Patrimonio Construido. Espainiako Arkitektura Institutuaren gaztelaniazko bertsioa (Valladolideko Unibertsitatea). http://ipce.mcu.es/pdfs/2000_Carta_Cracovia.pdf

[10] URANGA, E. J. eta ETXEPARE, L. 2015. «La intervención energética en el patrimonio edificado: un problema no resuelto». Revista $\mathrm{PH}, \mathbf{8 8}$, 260-262.

[11] URANGA, E.J. 2012. «Análisis del comportamiento energético de la vivienda del siglo Xx. Gipuzkoa: 1900-1980. El ejemplo del barrio de Gros de Donostia». Master Amaierako Lana. Euskal Herriko Unibertsitatea.

[12] Donostiako Eraikitako Hiri Ondarearen Plan Berezia (EHOPB). Donostiako Udala. Hasierako onespena: 2013ko martxoa.

[13] DRUOT, F., LACATON, A. eta VASSAL, J.P. 2007. Plus. Les grands ensembles de logements. Territoire d'exception. Gustavo Gili, Bartzelona.

[14] KURNITSKI, J., SAARI, A., KALAMEES, T., VUOLLE, M., NIEMELÄ, J. eta TARK, T. 2011. «Cost optimal and nearly zero (nZEB) energy performance calculations for residential buildings with REHVA definition for nZEB national implementation». Energy and Buildings, 43, 3279-3288.

[15] VAN UFFELEN, C. 2012. Passive Houses: Energy Efficient Homes. Braun. Salenstein.

[16] ETXEPARE, L., SAGARNA, M., LIZUNDIA, I., URANGA, E.J., AZCONA, L. eta ZUAZUA-GUISASOLA, N. Ikerketa proiektua: «Etxebizitzen Eraikuntza-analisia (1900-1980)». Deialdia: Ikerketan hasteko edo ikerketari berriro ekiteko Laguntzak (2012). Euskal Herriko Unibertsitateko Ikerketa Errektoreordetza. 
[17] Euskal Autonomia Erkidegoko eraikinak birgaitu eta hiria berroneratzeko 2010-2013 Plan Estrategikoa.Etxebizitza, Herri-lan eta Garraio Saila. Eusko Jaurlaritza.

[18] HAINBAT EGILEK. 2004. Guía de Arquitectura de Gipuzkoa, 1850-1960. Editorial Nerea, Donostia.

[19] AZCONA, L. 2016. Aspectos tipológicos de la vivienda social de posguerra (1939-1959). Ejemplificación en el territorio guipuzcoano. Doktorego Tesia. Arkitektura Saila. Euskal Herriko Unibertsitatea.

[20] LIZUNDIA, I. 2011. «La construcción de la fachada en los bloques de vivienda colectiva del Desarrollismo (1960-1975) en Gipuzkoa: una herencia muy cara». Libro de Actas del Séptimo Congreso Nacional de Historia de la Construcción. Instituto Juan de Herrera. 721-731.

[21] SAGARNA, M., LIZUNDIA, I. eta URANGA, E. J. 2013. «Gipuzkoa (1900-1980): Vivienda, Construccción, Energía (II)». Libro de Actas del VIII Congreso Nacional de Ingeniería Termodinámica. Universidad de Burgos. 590-596.

[22] http://www.codigotecnico.org/index.php/menu-recursos/menu-aplicaciones /282-herramienta-unificada-lider-calener

[23]http://www.minetur.gob.es/energia/desarrollo/EficienciaEnergetica/ CertificacionEnergetica/DocumentosReconocidos/Paginas/procedimientoscertificacion-proyecto-terminados.aspx

[22] External Thermal Insulation Composite System (ETICS). http://www. wacker.com/cms/en/industries/construction/facade/facade_eifs/eifs.jsp 